For citation: Kochetkov D. M., Larionova V. A., Vukovic D. B. (2017). Entrepreneurial Capacity of Universities and Its Impact on Regional Economic Growth. Ekonomika regiona [Economy of Region], 13(2), pp. 477-488

doi 10.17059/2017-2-13

UDC 332.1

JEL I250

D. M. Kochetkov a, b), V. A. Larionova ${ }^{\text {a) }}$, D. B. Vukovic ${ }^{\text {c) }}$

a) Ural Federal University (Ekaterinburg, Russian Federation; e-mail: kochetkovdm@hotmail.com)

b) Institute of Economics of the Ural Branch of RAS (Ekaterinburg, Russian Federation)

c) National Research Tomsk Polytechnic University (Tomsk, Russian Federation)

\title{
ENTREPRENEURIAL CAPACITY OF UNIVERSITIES AND ITS IMPACT ON REGIONAL ECONOMIC GROWTH
}

The scope of our research is the university as the key actor of economic change. Historically, it is possible to allocate four types of the university by analogy to four industrial revolutions. In the conditions of the fourth industrial revolution, there is a radical shift in the university model. From research and development and technology transfer, the university moves to the creation of the intellectual capital. The university does not simply conduct $R \& D$ for business but creates essentially new industries. The university becomes the center around which the new hi-tech enterprises grow. This phenomenon has been entitled entrepreneurial university that is the main actor of the entrepreneurial (startup) economy. In this study, we examined the different approaches to the evaluation of universities, first of all, global university rankings. Each ranking methodology assesses the different functional areas; a unified methodology of the evaluation of university as a complex system is currently lacking. At the same time, we tried to define the mechanism of the impact of the universities on regional economic growth grounding on a case of Russian universities. A comparative study of Novosibirsk and Tomsk universities has revealed key problem areas and barriers in the process of university engagement in regional economic systems. The findings will be used in further theoretical and applied research, as well as decision-making in the area of educational policy.

Keywords: higher education, entrepreneurial university, innovative cluster, university rankings, technology transfer, knowledge economy, economic development, regional policy, regional economy, indicators of university entrepreneurial activities

\section{Introduction}

At certain moments of history, societies make great breakthroughs known as technological revolutions. They interrupt a steady flow of social and economic evolution; they are always encouraged by an invention (sometimes not one), which sharply shifts the production possibility curve outward. The first technological revolution had an agrarian character. Its moving forces were irrigation and use of domesticated animals (first of all, horses) in agricultural works. The agrarian revolution generated great antique civilizations (Egypt, Mesopotamia, India). The invention of the steam engine at the end of the 17th century led to the appearance of large manufactory works that marked the first industrial revolution. The term "industrial revolution" was introduced in the 19th century by the French scientist Jerome Blanqui [1]. Machines replaced human labor. Starting with the weaving industry, revolution covered all industries and came to an end in the first half of 19th century with the emergence of modern fabric

\footnotetext{
${ }^{1}$ (c) Kochetkov D. M., Larionova V. A., Vukovic D. B. Text. 2017.
}

manufacturing. At the turn of the 19th-20th centuries, the second industrial revolution, which introduced the internal combustion engine, electrification, and mass assembly line production, began. Since then, hydrocarbon resources have become the key factor in not only economy, but in all global policy and history as well. The third industrial revolution arose due to the invention of the computer, which empowered wide automation of production operations. In the 1990th of the 20th century, the emergence of the Internet global network marked the entrance of the mankind into the new information era. Rates of scientific and technical progress became determined by the Moore's law, according to which productivity of the processor is doubled every 24 months. Now we are on the threshold of the fourth industrial revolution characterized by a rapid development of a variety of industries, such as robotics, artificial intelligence, neuroscience, brain engineering, and 3D printing production. An advance in each of these areas leads to a chain reaction due to the externality effect. However, in the 21st century, the mankind is expected to face the most serious challenges in the 
history. It is essential to note at least two of them. First, the proven oil reserves may come to an end already in the middle of the century. Secondly, the current level of carbon emissions in the atmosphere can lead to a catastrophic temperature rise at the end of the century. Therefore, technologies of green economy will play an increasingly important role in social and economic development.

Based on inventions and new technologies, social and economic evolution has always gone hand in hand with science. Historically, it is possible to allocate four types of universities by analogy to four industrial revolutions. The first European universities were focused on theology and philosophy; with the advent of the early modern period, fundamental research began to develop rapidly. The subsequent changes in the social and economic structure of societies brought the issues of knowledge transfer and professional training to the forefront. Under the conditions of the post-industrial society, universities became market consultants for economic agents on a large scale.

With the advent of the fourth industrial revolution, knowledge has begun to play the key role in the social and economic development of the mankind. It has also become a production factor or resource. A model of the knowledge-based society was offered by Henry Etzkowitz. The given model is known as a triple helix of university - industry-government [2, 3]. Etzkowitz argues with those researchers who consider a phenomenon of innovative regions (for example, Silicon Valley) to be unique [4]. In his opinion, the triple helix model is reduced to concrete mechanisms and institutional conditions. The entrepreneurial university is right in the center of the innovative cluster. This hypothesis has been supported by a number of empirical studies [4-8].

University plays a central role in the knowledge-based model of regional economic growth being the main producer of knowledge in the region. Thus, the model of knowledge generation can be summarized in terms of the production process. It is important to draw a line between the exchange and distribution. In the case of exchange, we deal with business relationships between two or more economic agents. Distribution means the free circulation and use of new knowledge by an unlimited range of economic agents. Distribution of knowledge can create externalities that promote regional economic growth. In other words, this is the process of knowledge transfer.

Our question is how to measure the entrepreneurial capacity of universities and its impact on regional economic growth. Obviously, it consists of two parts. First, we compared different tech- niques of university ranking in terms of knowledge transfer. Then, we analyzed the positions of Russian universities in various international rankings. We also assumed that science and higher education have a prominent impact on the regional economic development. There are many case studies on the subject [9], but not enough larger generalizing theoretical research $[10,11]$. Further, we analyzed the position of Russian universities in various international rankings. Grounding on the cases of two Russian regions (Novosibirsk and Tomsk regions), we examinedthe possibilities and conditions for the development of the entrepreneurial potential of the university, as well as restrictions on the use of formal criteria. The results are important both for practice and for policy-making in the field of science and higher education.

\section{Data and Methods of University Rankings}

Till 2009, QS-THES, issued by Times Higher Education (THE) together with Quacquarelli Symonds (QS), was considered to be the most authoritative world ranking of universities. According to this methodology, $40 \%$ of estimation relied upon a poll of experts; $10 \%$-on the opinion of employers; $20 \%$ - on the ratio of students/teachers; $20 \%$ - on the quantity of citation on the employees' publications in Scopus over the last 5 years; $5 \%$ - on the shares of foreign students and foreign teachers. The technique was rather arguable; accordingly, in 2009 THE signed a contract with a leader in the information industry Thomson Reuters (TR). After brisk discussions on methodology in 2011/12 years, the first release of the World University Ranking (WUR) appeared. The methodology includes 13 indicators in 5 directions ${ }^{1}$ :

- Teaching

- Research

- Citations

- International outlook

- Industry income.

It should be noted that the indicator of industrial profit implies accounting of knowledge transfer; however, its weight in ranking calculation constitutes only $2.5 \%$.

The company QS currently releases its own rating $^{2}$, with the methodology remaining essentially the same. Besides, QS releases rankings in sub-

\footnotetext{
1 World University Rankings 2015-2016 methodology. Retrieved from: https:/www.timeshighereducation.com/news/ ranking-methodology-2016 (date of access: 02.04.2016).

${ }^{2}$ QS World University Rankings ${ }^{\bowtie}$ explained. Retrieved from: http://www.qs.com/qs-world-university-rankings.html (date of access: 02.04.2016).
} 
ject categories ${ }^{1}$; in some countries (for example, Russia), the process of reorientation to these criteria is taking place.

Another recognized world ranking is the Academic Ranking of World Universities (ARWU), also known as the Shanghai rating. At the heart of its methodology, 5 criteria $^{2}$ lie:

- Quality of Education;

- Quality of Faculty;

- Research Output;

- Per Capita Performance.

Performance indicators are generally calculated on the basis of the quantity of the Nobel winners; indicators of publications and citations are determined on the basis of Thomson Reuters Web of Science and, in particular, the quantity of publications in the world most recognized journals Science and Nature.

The CWTS Leiden Ranking ${ }^{3}$ also takes a data set from Thomson Reuters Web of Science for a basis; the indicators are grouped in 2 directions: Impact indicators and Collaboration indicators. Leiden Ranking has a number of specific features of calculation of indicators. Thus, the calculation includes not all publications in Web of Science, but only the core publications matching the certain criteria. All indicators have two groups-size-dependent and size-independent. The second group implies a proportion from the total quantity of employees of university that allows a relative indicator of the academic performance independently from the size to be estimated. In parallel with the classical accounting of the article quantity ( 1 article is considered in the list of publications of each of the co-authors; 1 article is considered in the list of publications of university independently from the quantity of authors), a share (fraction) accounting is conducted. The second method is considered to be more preferable by the authors of the ranking.

Thus, it is obvious that almost all leading world rankings estimate only academic indicators. At the same time, the mission of an entrepreneurial university as the main actor of the knowledge economy is technology transfer, or knowledge transfer in a wider understanding. The only exception is the World University Ranking from THE; however, this indicator has a weight of only $2.5 \%$ in the calculation. Subsequently, there is an essential

\footnotetext{
${ }^{1} 29$ subjects ranked: first QS World University Rankings ${ }^{\oplus}$ by Subject. Retrieved from: http://www.qs.com/qs-world-university-rankings-by-subject.html (date of access: 02.04.2016).

${ }^{2}$ Academic Ranking of World Universities. Retrieved from: http://www.shanghairanking.com/ARWU-Methodology-2015. html (date of access: 02.04.2016).

${ }^{3}$ CWTS Leiden Ranking. Retrieved from: http://www.leidenranking.com/methodology (date of access: 02.04.2016).
}

need for a joint quantitative and qualitative methodology for estimating universities' entrepreneurial capability.

Global University Venturing (GUV) ranking has made an attempt to estimate the performance of technology transfer offices (TTO) of the leading world universities ${ }^{4}$. The technique is based on the data on disclosures, patents and licenses, revenues from technological transfer activities, and quantity of the academic startups (spinouts). The ranking is of great practical importance. However, the authors of the ranking recognized that its weakness is statistics: the data is provided by universities; some universities do not provide any information at all. Another ranking also based on the quantitative data is the Thomson Reuters Ranking the World's Most Innovative Universities ${ }^{5}$. The technique also considers the number of patents; besides, indicators of citations and quantity of articles in collaboration with industry ${ }^{6}$ are analyzed. Thus, World's Most Innovative Universities represents an intermediate alternative between the academic and entrepreneurial rankings of universities.

The problem of quantitative indicators is that they show the final condition of a system, failing to reveal the mechanisms of its forming. Therefore, the institutional analysis of entrepreneurial university should be applied. Such an attempt was made in the $\mathrm{UK}^{7}$, with its methodology being focused on 5 following directions:

- Mission, Governance, and Strategy;

- Stakeholder Engagement;

- Entrepreneurship Education;

- Internalization;

- Knowledge Transfer, Exchange and Support.

According to the authors of the methodology, these indicators influence the academic excellence, quantity of innovations, and competitiveness of a university. The corresponding questionnaire has been developed ${ }^{8}$. Table 1 represents the comparative analysis of various rankings.

${ }^{4}$ Global University Venturing. Retrieved from: http://www. globaluniversityventuring.com/article.php/3919/guv-tto-andcombined-world-rankings-2014?tag_id=534 (date of access: 02.04.2016).

${ }^{5}$ Ranking the World's Most Innovative Universities. Retrieved from: http://www.reuters.com/article/idUSL1N11K16Q201509 15 (date of access: 02.04.2016).

6 Methodology: Ranking the World's Most Innovative Universities. Retrieved from: http://www.reuters.com/most-innovative-universities/methodology (date of access: 02.04.2016).

7 Entrepreneurial University Leaders Programme. Retrieved from: http://eulp.co.uk/ (date of access: 02.04.2016).

${ }^{8}$ NCEE The University Entrepreneurial Scorecard (Reviewing the Entrepreneurial Potential of a University. Retrieved from: 
Table 1

Different ranking techniques

\begin{tabular}{|l|c|c|c|c|c|c|c|}
\hline \multicolumn{1}{|c|}{$\begin{array}{c}\text { Indicator/ } \\
\text { Ranking }\end{array}$} & WUR & QS & ARWU & $\begin{array}{c}\text { CWTS Leiden } \\
\text { Ranking }\end{array}$ & GUV $^{5}$ & $\begin{array}{c}\text { Thomson } \\
\text { Reuters }^{6}\end{array}$ & EULP $^{7}$ \\
\hline Data & $\begin{array}{c}\text { qualitative/ } \\
\text { quantitative }\end{array}$ & $\begin{array}{c}\text { qualitative/ } \\
\text { quantitative }\end{array}$ & quantitative & quantitative & quantitative & quantitative & qualitative \\
\hline $\begin{array}{l}\text { Research } \\
\text { Performance }\end{array}$ & + & + & + & + & & \\
\hline $\begin{array}{l}\text { Teaching } \\
\text { Performance }\end{array}$ & + & + & + & & & & \\
\hline Internalisation & + & + & & & & & + \\
\hline $\begin{array}{l}\text { Publications \& } \\
\text { Impact }\end{array}$ & + & + & + & & + & + & + \\
\hline $\begin{array}{l}\text { Knowledge } \\
\text { Transfer }\end{array}$ & + & & & & & & + \\
\hline $\begin{array}{l}\text { Entrepreneurial } \\
\text { Education }\end{array}$ & & & & & & & + \\
\hline Strategy & & & & & & + \\
\hline
\end{tabular}

${ }^{1}$ World University Rankings 2015-2016 methodology. Retrieved from: https://www.timeshighereducation.com/news/rankingmethodology-2016 (date of access: 02.04.2016).

${ }^{2}$ QS World University Rankings ${ }^{\circledast}$ explained. Retrieved from: http://www.qs.com/qs-world-university-rankings.html (Date of access 02.04.2016)

${ }^{3}$ Academic Ranking of World Universities. Retrieved from: http://www.shanghairanking.com/ARWU-Methodology-2015.html (date of access: 02.04.2016).

${ }^{4}$ CWTS Leiden Ranking. Retrieved from: http://www.leidenranking.com/methodology (date of access: 02.04.2016).

${ }^{5}$ Global University Venturing. Retrieved from: http://www.globaluniversityventuring.com/article.php/3919/guv-tto-and-combined-world-rankings-2014?tag_id=534 (date of access: 02.04.2016).

${ }^{6}$ Methodology: Ranking the World's Most Innovative Universities. Retrieved from: http://www.reuters.com/most-innovative-universities/methodology (date of access: 02.04.2016).

${ }^{7}$ Entrepreneurial University Leaders Programme. Retrieved from: http://eulp.co.uk/ (date of access: 02.04.2016).

Table 2

Correlation analysis of various university rankings with knowledge transfer indicators

\begin{tabular}{|l|c|c|c|c|c|c|}
\hline \multicolumn{1}{|c|}{ Indicator } & r_QS & t_QS & r_ARWU & t_ARWU & r_THE & t_THE \\
\hline Disclosures & 0.46804 & 2.33 & 0.31322 & 1.49 & 0.10075 & 0.46 \\
\hline Patents & 0.71157 & 4.11 & 0.13830 & 0.64 & 0.29700 & 1.41 \\
\hline License & -0.07153 & -0.34 & -0.10088 & -0.48 & -0.03475 & -0.17 \\
\hline Revenue, mln \$ & -0.00312 & -0.01 & -0.04615 & -0.22 & -0.22374 & -1.09 \\
\hline Startups & 0.07651 & 0.35 & -0.01300 & -0.06 & -0.05040 & -0.24 \\
\hline Indicator & r_WUR & t_WUR & r_TR & t_TR & r_GUV & t_GUV \\
\hline Disclosures & 0.36063 & 1.74 & 0.63267 & 2.82 & 0.67961 & 3.82 \\
\hline Patents & 0.32891 & 1.57 & 0.18201 & 0.69 & 0.67599 & 3.79 \\
\hline License & -0.10481 & -0.50 & 0.10300 & 0.39 & 0.31057 & 1.48 \\
\hline Revenue, mln \$ & -0.06027 & -0.29 & 0.17572 & 0.67 & 0.33183 & 1.59 \\
\hline Startups & 0.00424 & 0.02 & 0.29515 & 1.14 & 0.60218 & 3.21 \\
\hline
\end{tabular}

The authors studied the relationship between the positions of the university in different rankings (expressed in points) and actual values of the abovementioned indicators of effective knowledge transfer using a correlation analysis. The calculation was conducted on the basis of the following data: number of disclosures, patents, licenses, startups, and revenues of universities from tech-

http://eulp.co.uk/ (date of access: 02.04.2016). nology transfer. Results of calculation are shown in Table 2. The levels of significance of the obtained coefficients of correlation are presented in the next columns.

As apparent from Table 2, the rankings ARWU, THE and integral world ranking (THE + ARWU + QS) poorly correlate with the indicators of entrepreneurial activities of the universities; thus, the level of significance of the found coefficients of correlation are below the critical value of Student's 
coefficient equal to 2.1 for confidential probability 0.95 and corresponding degrees of freedom. Moderate relationship $(r=0.63267)$ is observed only at WUR ranking with the disclosure indicator, whereas correlation with other indicators is absent. It is important that one of the most authoritative university rankings QS reflects the relationship between two indicators of university entrepreneurial activities, i.e. disclosures $(0.46804)$ and patents issued (0.71157); thus, the coefficient of correlation with patents is much greater, and its level of significance is high enough.

The GUV ranking is calculated on the basis of technology transfer indicators; therefore, correlation with the indicators of disclosures, patents, and startups is more than 0.6 , and significance levels exceed 3. Nevertheless, no ranking reflects the relationship between the entrepreneurial activity and the number of licenses and revenues from academic entrepreneurship.

It should also be noted that quantitative indicators estimate only the final condition of a system, failing to reveal the mechanisms of its formation. Moreover, qualitative indicators used in a number of rankings analyse formal university rules, while a number of researchers have reported a prevailing role of informal factors and restrictions in the development of academic entrepreneurship. Thus, Guerrero et al. have come to the conclusion that such informal factors as attitudes towards entrepreneurship and role models have more value than formal support measures to entrepreneurship or education and training programs [12]. The given approach to the analysis of universities starts with D. North's definition of institutions as formal rules and informal restrictions [13].

The difference between results of rankings claims that existing techniques are not interrelated and estimate absolutely different functional areas. Meanwhile, the university is a complex system, and it is essential to consider it in terms of holism. The universal methodology of estimation is still absent. Besides, available statistical data is not enough by the current moment.

\section{Russian Universities in Global Rankings}

Table 3 presents a comparative analysis of the positions of Russian universities in various global rankings. Apparently, Russian universities are represented here rather modestly. Among the applicants for relatively high positions, there are mainly universities of Moscow and St. Petersburg, and only three non-capital universities, in particular, Novosibirsk State University, Tomsk State University and Tomsk Polytechnic University, are among the top ten universities in the country.
The achievements of Russian universities are marked only by traditional world rankings, which assess the quality of teaching and research, and sometimes the process of internalization. As for the innovative rankings based on knowledge transfer, Russian universities are not represented in them at all. Of course, one could argue that the rankings such as Thomson Reuters Most Innovative Universities and Global University Venturing include only 100 universities each. But let's compare the key performance indicators of knowledge transfer-patents and licenses issued, and university startups - of 25 universities included in the Global University Venturing (medium) and 14 Russian universities presented in Table 3 (see Table 4). We intentionally did not take the universities of Moscow and St. Petersburg for analysis, as metropolitan areas have specific features and operating conditions. On the one hand, they are able to exploit practically nationwide resources (primarily, intellectual); on the other hand, their impact is not limited to a particular region; they affect the national economy and society as a whole.

It is obvious that only half of the analyzed universities have figures comparable with the world's leading entrepreneurial universities (although almost all of them have a strong technical profile). Almost all patents are Russian, which significantly narrows the target audience to the Russian companies and branches of international companies conducting operations in Russia. Hence, the rates of issued licenses are extremely low. On the one hand, this is due to a low effective demand for inventions by corporate enterprises, on the other hand, we can assume that the subject of research of regional universities does not correspond to the structure of the regional economies and strategic priorities. Another way of knowledge transfer is the establishment of academic high-tech enterprises, but according to this indicator, we significantly lag behind the Western universities.

In general, none of the analyzed universities can be considered competitive on the global scene by the level of entrepreneurial potential. In our mind, the problem is institutional, i.e. there are no effective institutions of knowledge transfer in Russia. This is largely due to the fact that the vast majority of universities in Russia are in the federal jurisdiction. Within the regional socio-economic and institutional configuration, they are «foreign bodies.» Although attempts to create «helix-type» clusters - university-business - government (federal or local) - are undertaken almost everywhere, their success is restricted by a lack of formal mechanisms for coordination between research, regional economies and local political structures. 
Table 3

Russian universities in global rankings

\begin{tabular}{|c|c|c|c|c|c|c|}
\hline University & $\mathbf{Q S}^{1}$ & WUR $^{2}$ & $\mathrm{ARWU}^{3}$ & CWTS $^{4}$ & $\mathbf{T R}^{5}$ & GUV $^{6}$ \\
\hline Lomonosov Moscow State University & 108 & 188 & 87 & 296 & - & - \\
\hline Saint-Petersburg State University & 258 & $401-500$ & $301-400$ & 682 & - & - \\
\hline Novosibirsk State University & 291 & $401-500$ & $401-500$ & - & - & - \\
\hline Bauman Moscow State Technical University & 306 & $601-800$ & - & - & - & - \\
\hline $\begin{array}{l}\text { Moscow Institute of Physics and Technology (MIPT / } \\
\text { Moscow Phystech) }\end{array}$ & 350 & $301-350$ & - & - & - & - \\
\hline $\begin{array}{l}\text { Moscow State Institute of International Relations (MGIMO } \\
\text { University) }\end{array}$ & 350 & - & - & - & - & - \\
\hline Tomsk State University & 377 & $501-600$ & - & - & - & - \\
\hline National Research Tomsk Polytechnic University & 400 & $501-600$ & - & - & - & - \\
\hline $\begin{array}{l}\text { National Research Nuclear University MEPhI (Moscow } \\
\text { Engineering Physics Institute) }\end{array}$ & $401-410$ & $401-500$ & - & - & - & - \\
\hline $\begin{array}{l}\text { National Research University Higher School of Economics } \\
\text { (HSE, Moscow) }\end{array}$ & $411-420$ & $401-500$ & - & - & - & - \\
\hline Peter the Great Saint-Petersburg Polytechnic University & $411-420$ & $601-800$ & - & - & - & - \\
\hline Kazan (Volga region) Federal University & $501-550$ & $401-500$ & - & - & - & - \\
\hline Far Eastern Federal University & $551-600$ & - & - & - & - & - \\
\hline National Research Saratov State University & $551-600$ & $801+$ & - & - & - & - \\
\hline Southern Federal University & $551-600$ & $801+$ & - & - & - & - \\
\hline The National University of Science and Technology MISIS & $601-650$ & $801+$ & - & - & - & - \\
\hline RUDN University & $601-650$ & $801+$ & - & - & - & - \\
\hline Ural Federal University & $601-650$ & $801+$ & - & - & - & - \\
\hline Lobachevsky University & $701+$ & $801+$ & - & - & - & - \\
\hline Novosibirsk State Technical University & $701+$ & $801+$ & - & - & - & - \\
\hline Plekhanov Russian University of Economics & $701+$ & - & - & - & - & - \\
\hline Voronezh State University & $701+$ & $801+$ & - & - & - & - \\
\hline ITMO University & - & $351-400$ & - & - & - & - \\
\hline $\begin{array}{l}\text { National Research University of Electronic Technology } \\
\text { (MIET) }\end{array}$ & - & $801+$ & - & - & - & - \\
\hline Samara State Aerospace University & - & $801+$ & - & - & - & - \\
\hline Sechenov First Moscow State Medical University & - & $801+$ & - & - & - & - \\
\hline Siberian Federal University & - & $801+$ & - & - & - & - \\
\hline
\end{tabular}

${ }^{1}$ Source: QS World University Rankings. Retrieved from: https://www.topuniversities.com/university-rankings/world-university-rankings/2016 (date of access: 07.02.2017).

${ }^{2}$ Source: World University Rankings. Retrieved from: https://www.timeshighereducation.com/world-university-rankings (date of access: 07.02.2017).

${ }^{3}$ Source: Academic Ranking of World Universities. Retrieved from: http://www.shanghairanking.com (date of access: 07.02.2017).

${ }^{4}$ Source: CWTS Leiden Ranking. Retrieved from: http://www.leidenranking.com/ranking/2016/list (date of access: 07.02.2017)

${ }^{5}$ Source: Ranking the World's Most Innovative Universities. Retrieved from: http://www.reuters.com/article/amers-reuters-ranking-innovative-univers-idUSL2N1C406D (date of access: 07.02.2017).

${ }^{6}$ Source: Global University Venturing. Retrieved from: http://www.globaluniversityventuring.com/article.php/3919/guv-tto-andcombined-world-rankings-2014?tag_id=534 (date of access: 07.02.2017).

Universities' Engagement in Regional

Economic Systems: a Case of Novosibirsk and Tomsk Regions

The entrepreneurial potential of a regional university is determined by its engagement into regional economic system; again, we note that the metropolitan high schools have a fundamentally different level of interaction with the economy both in terms of resource provision, and in the mechanism of knowledge transfer. To illustrate this idea of engagement, we conducted a comparative analysis of the universities of Novosibirsk and Tomsk regions. The choice of these regions is preconditioned by their similar geographical and economic position (30th and 29th place in the ranking of Russian regions in terms of socio-economic status, respectively ${ }^{1}$ ).

Retrieved from: http://riarating.ru/regions_rankings/ 20160615/630026438.html. 
Indicators of knowledge transfer of leading Russian universities

\begin{tabular}{|l|c|c|c|c|}
\hline \multicolumn{1}{|c|}{ University } & $\begin{array}{c}\text { Patents obtained } \\
\text { (Russia) }\end{array}$ & $\begin{array}{c}\text { Patents obtained } \\
\text { (international) }\end{array}$ & $\begin{array}{c}\text { Licenses } \\
\text { issued }\end{array}$ & Startups \\
\hline Novosibirsk State University $^{1}$ & 22 & 0 & 0 & 0 \\
\hline Tomsk State University $^{1}$ & 64 & 0 & 7 & 10 \\
\hline Tomsk Polytechnic University $^{1}$ & 164 & 3 & 11 & 0 \\
\hline Kazan (Volga region) Federal University $^{2}$ & 37 & 0 & 2 & 0 \\
\hline Far Eastern Federal University $^{3}$ & 111 & 1 & 3 & 1 \\
\hline Saratov State University $^{2}$ & 20 & 1 & 30 & 0 \\
\hline Southern Federal University $^{4}$ & 51 & 0 & 19 & 0 \\
\hline Ural Federal University $^{5}$ & 74 & 0 & 0 & 6 \\
\hline Lobachevsky University $^{2}$ & 21 & 0 & 1 & 0 \\
\hline Novosibirsk State Technical University $^{1}$ & 57 & 0 & 1 & 1 \\
\hline Voronezh State University $^{6}$ & 86 & 0 & 5 & 4 \\
\hline Samara State Aerospace University $^{2}$ & 77 & 0 & 0 & 4 \\
\hline Siberian Federal University $^{1}$ & 115 & 31 & 6 & 2 \\
\hline Global University Venturing (medium values) $^{2}$ & 74.79 & 68.64 & 9.44 & \\
\hline
\end{tabular}

${ }^{1}$ Nauchnyy potentsial vuzov Sibirskogo federalnogo okruga [The scientific potential of the Siberian Federal District HEIs .2015]. (2016). In: A. O. Ladny (Ed.). Saint Petersburg: Saint Petersburg Electrotechnical University.

${ }^{2}$ Nauchnyy potentsial vuzov Privolzhskogo federalnogo okruga [The scientific potential of the Volga Federal District HEIs. 2015]. (2016). In: A. O. Ladny (Ed.). Saint Petersburg: Saint Petersburg Electrotechnical University.

${ }^{3}$ Nauchnyy potentsial vuzov Dalnevostochnogo federalnogo okruga [The scientific potential of the Far Eastern Federal District HEIs. 2015]. (2016). In: A. O. Ladny (Ed.). Saint Petersburg: Saint Petersburg Electrotechnical University.

${ }^{4}$ Nauchnyy potentsial vuzov Yuzhnogo federalnogo okruga [The scientific potential of the Southern Federal District HEIs. 2015]. (2016). In: A. O. Ladny (Ed.). Saint Petersburg: Saint Petersburg Electrotechnical University.

${ }^{5}$ Nauchnyy potencial vuzov Uralskogo federalynogo okruga [The scientific potential of the Ural Federal District HEIs 2015]. (2016). In: A. O. Ladny (Ed.). Saint Petersburg: Saint Petersburg Electrotechnical University.

${ }^{6}$ Nauchnyy potentsial vuzov Tsentralnogo federalnogo okruga [The scientific potential of the Central Federal District HEIs. 2015]. (2016). In: A. O. Ladny (Ed.). Saint Petersburg: Saint Petersburg Electrotechnical University.

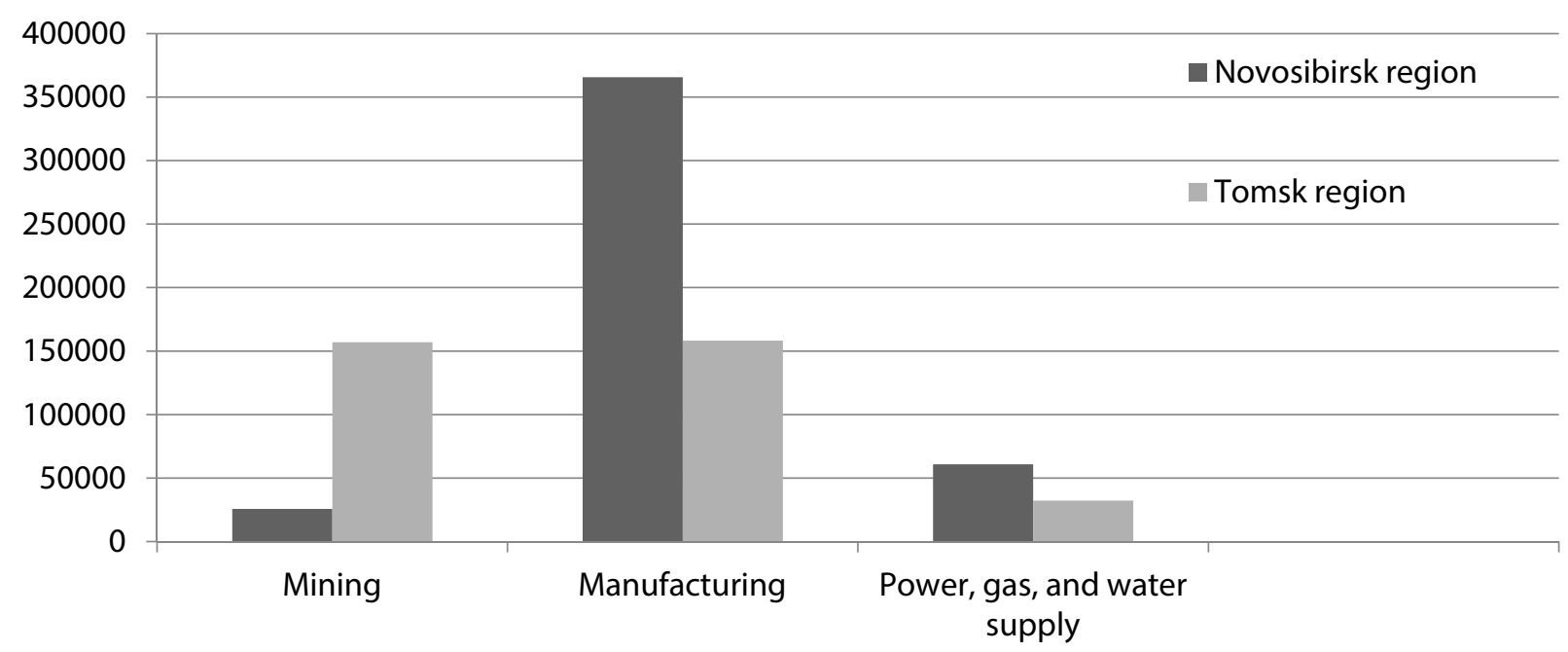

Fig. 1. Industrial composition of the economies of Novosibirsk and Tomsk regions (Source: Federal State Statistics Service. Retrieved from: http://www.gks.ru/bgd/regl/b16_14p/lssWWW.exe/Stg/d02/13-01.doc (date of access: 25.02.2017))

The economic structures of Novosibirsk and Tomsk regions differ from each other (Figure 1).

Tomsk region has an advantage in mining industries - the region has reserves of hydrocarbons, Novosibirsk is leading in the manufacturing and energy industries. It would seem that this situation should facilitate the process of knowledge transfer in Novosibirsk, but the figures tell a different story. We also have decided to conduct a comparative analysis of the dynamics of investment in fixed capital per capita (Figure 2), because this indicator determines the demand for technological innovations. Russia is still far from the stage when the consumer innovative products will de- 


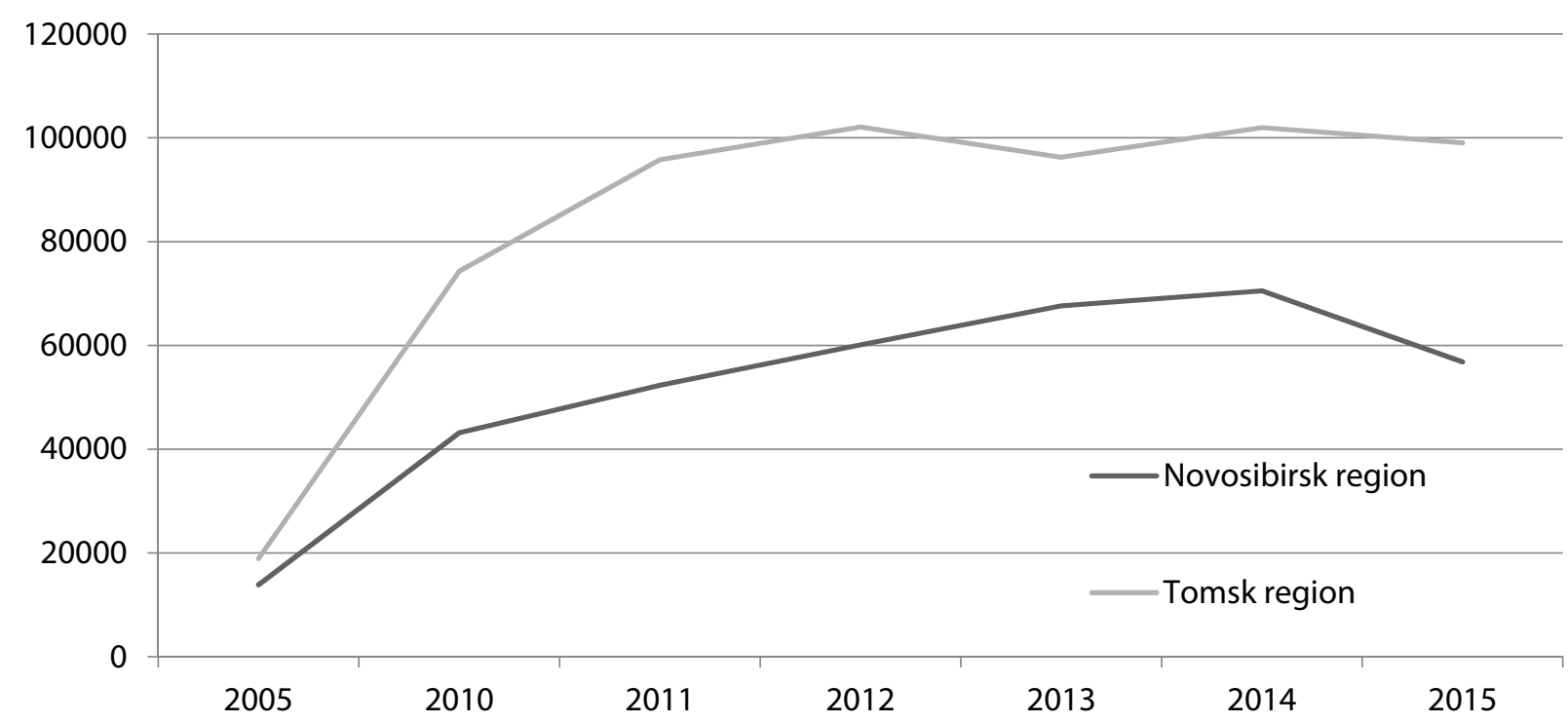

Fig. 2. Dynamics of capital investment per capita (Source: Federal State Statistics Service. Retrieved from: http://www.gks.ru/bgd/ regl/b16_14p/lssWWW.exe/Stg/d03/23-02.doc (date of access: 25.02.2017))

termine the demand for technology. There is a significant advantage of the Tomsk region here - the region occupies 23rd place in Russia by this indicator, Novosibirsk region is 55th. In addition, the gap continues to widen. Grounding on this, we can conclude that the first factor in the realization of the entrepreneurial potential of a regional university is a capital investment, as this indicator measures the demand for research and development.

Technological priorities of Novosibirsk and Tomsk regions (Table 5) differ from each other even in stylistics: in the case of Novosibirsk, we have a list of specific technologies; Tomsk strategy outlines broad technology areas. In addition, the technological priorities of the Tomsk region are mainly based on the innovative development of traditional industries, while the strategy of Novosibirsk region is aimed at the development of the «new» economy. Perhaps, therein lays the success of Tomsk universities - research and development are used in existing industries and companies, which significantly facilitates the process of knowledge transfer.

It should be noted that the research areas of Tomsk universities are much closer to the technological priorities of the regional strategy than in the case of Novosibirsk. Tomsk Polytechnic University has a larger focus on computer science and software engineering, but in general, the two Tomsk universities in their scientific development accurately repeat the configuration of the regional economy. Due to this, they conduct a successful knowledge transfer in the real economy. In turn, in Novosibirsk, we can see a large gap between the economic development strategy and actually developing research fields. Besides, we have com- pared the performance of leading Novosibirsk and Tomsk universities in terms of number and size of research groups, participation in the government innovation policy measures, the number of technology platforms and high-tech clusters, and the number of partnerships in the real economy (Table 6).

We can note a significant advantage of Tomsk universities in the number and size of research teams. This fact illustrates the innovation cycle by Schumpeter once again: at the beginning of any innovation, there is a scientific invention, any attempts to divide science and innovation (basic and applied research) reduce the quality and quantity of knowledge production. Of course, research advantage also has a positive effect on the performance of knowledge transfer. In addition, the Tomsk universities far exceed Novosibirsk ones by the number of partners in the real economy. According to this indicator, Tomsk Polytechnic University is one of the leading regional institutions in Russia, which also has the largest number of technology platforms.

Almost unexceptionally, formal coordination mechanisms between research and regional economies are present. Hence, we can assume that the development and realization of the entrepreneurial potential of universities depend on informal mechanisms of interaction as well (personal communication, administrative resource, Governor's position). Therefore, quantitative research in the field of regional knowledge transfer systems cannot provide a definite answer; further case studies with the use of tools of institutional analysis are needed. 
Table 5

Compliance of industrial and technological priorities of socio-economic development strategies and application areas of results of universities' R\&D (Novosibirsk and Tomsk regions)

\begin{tabular}{|c|c|}
\hline $\begin{array}{c}\text { Industrial and technological priorities of regional } \\
\text { development }\end{array}$ & Universities' research and development \\
\hline Novosibirsk region $^{1}$ & Novosibirsk Siale Universily \\
\hline \multirow{3}{*}{$\begin{array}{l}\text { Nanotechnology, semiconductors and microelectronics; } \\
\text { Optoelectronics; } \\
\text { Bioelectronics; } \\
\text { Biosensors; } \\
\text { Information systems; } \\
\text { Software engineering; } \\
\text { Metal and composite materials; } \\
\text { Bioenergy; } \\
\text { Diagnostic tools and medicines; } \\
\text { Solar panels; } \\
\text { Energy-saving technologies; } \\
\text { Micro machines; } \\
\text { Intelligent robots; } \\
\text { Components for the vehicles; } \\
\text { Technology of underground construction; } \\
\text { Technology and equipment for the measurement of en- } \\
\text { vironmental parameters; } \\
\text { Technology of cleaning and recycling of waste; } \\
\text { Crystallography; } \\
\text { Radiation technologies; } \\
\text { Pulse technology; } \\
\text { Electron beam technology }\end{array}$} & $\begin{array}{l}\text { Thermal and hydro power, chemical engineering, environment } \\
\text { protection; } \\
\text { Energy. Conversion of hydrocarbon resources to synthesis gas } \\
\text { for charging of the fuel cells; } \\
\text { Medicine, pharmaceutics; } \\
\text { Professional equipment. Scientific studies (particular, SRS spec- } \\
\text { troscopy), holography, lithography, interferometry and cytome- } \\
\text { try, quality control of semiconductors, etc. }\end{array}$ \\
\hline & Novosibirsk State Technical University $^{4}$ \\
\hline & $\begin{array}{l}\text { Geophysical exploration; } \\
\text { Radio engineering, microwave devices; } \\
\text { Construction materials; } \\
\text { Power generating industry; } \\
\text { Electrical engineering, development of electromagnetic motors; } \\
\text { Small-scale hydropower; } \\
\text { Computer modelling; } \\
\text { Methods of sampling, data interpretation and presentation of } \\
\text { information on the display system for individual use (SRI); } \\
\text { Image processing, forensics; } \\
\text { User technical support centers; } \\
\text { Protection of forests; } \\
\text { Medical diagnostics }\end{array}$ \\
\hline & Tomsk State University ${ }^{2}$ \\
\hline \multirow[t]{3}{*}{$\begin{array}{l}\text { Chemical production; } \\
\text { Manufacture of coke, refined petroleum and nuclear } \\
\text { materials; } \\
\text { Manufacture of machinery and equipment; } \\
\text { Mining; } \\
\text { Food industry; } \\
\text { Pharmaceuticals and high-tech medicine; } \\
\text { Information technology; } \\
\text { Construction industry; } \\
\text { Agriculture, forestry, and fishing; } \\
\text { Woodworking industry }\end{array}$} & $\begin{array}{l}\text { lial production (nanotecnnol } \\
\text { laceuticals, strategic materials } \\
\text { lture; } \\
\text { osis of inorganic and organic } \\
\text { al equipment; } \\
\text { sional equipment; } \\
\text { g (including oil production); } \\
\text { urgy; } \\
\text { ogy; }\end{array}$ \\
\hline & Tomsk Polytechnic University $^{2}$ \\
\hline & $\begin{array}{l}\text { Advanced materials; } \\
\text { Telecommunications, processing and protection of } \\
\text { information; } \\
\text { Electronics; } \\
\text { Radiographic equipment; } \\
\text { Automation of manufacturing; } \\
\text { Medicine, medical devices; } \\
\text { Chemical and jewelry production; } \\
\text { Emergency services; } \\
\text { Bioengineering; } \\
\text { Recycling; } \\
\text { Geology; } \\
\text { Electrical engineering; }\end{array}$ \\
\hline
\end{tabular}


The end of the table 5

\begin{tabular}{|l|l|}
\hline $\begin{array}{c}\text { Industrial and technological priorities of regional } \\
\text { development }\end{array}$ & \multicolumn{1}{|c|}{ Universities' research and development } \\
\hline & Nanomaterials; \\
Wastewater treatment; & Metallurgy, casting technology; \\
Pipeline transportation; & Mining industry; \\
Acoustic devices; & Small power; \\
& Space Industry; \\
& Nuclear power \\
\hline
\end{tabular}

${ }^{1}$ Strategy for Socio-Economic Development of the Novosibirsk region for the period up to 2025. Act 474 from 03.12.2007.

${ }^{2}$ Informatsionno-analiticheskie materialy po perspektivnym nauchnym i innovatsionnym razrabotkam obrazovatelnykh i nauchnykh organizatsiy [Informational and analytical materials on promising research and innovative development of educational and research institutions]. (2015). In: G.I. Bakhturin (Ed.). Issue 2. Moscow: Ministry of Education and Science of the Russian Federation. ${ }^{3}$ Strategy for Socio-Economic Development of the Tomsk region until 2030. Retrieved from: https://tomsk.gov.ru/Strategiyarazvitiya-Tomskoy-oblasti-do-2020 (date of access: 25.02.2017).

${ }^{4}$ Informatsionno-analiticheskie materialy po perspektivnym nauchnym i innovatsionnym razrabotkam obrazovatelnykh i nauchnykh organizatsiy [Informational and analytical materials on promising research and innovative development of educational and research institutions]. (2015). In: G.I. Bakhturin (Ed.). Issue 2. Moscow: Ministry of Education and Science of the Russian Federation.

Table 6

Comparative analysis of research indicators of Novosibirsk and Tomsk universities

\begin{tabular}{|l|c|c|c|c|c|}
\hline \multicolumn{1}{|c|}{ University } & $\begin{array}{c}\text { Number of } \\
\text { research } \\
\text { teams }\end{array}$ & $\begin{array}{c}\text { Number of } \\
\text { employees engaged } \\
\text { in research teams }\end{array}$ & $\begin{array}{c}\text { Number of } \\
\text { technological } \\
\text { platforms }\end{array}$ & $\begin{array}{c}\text { Number of } \\
\text { high-tech } \\
\text { clusters }\end{array}$ & $\begin{array}{c}\text { Number of } \\
\text { partnerships in } \\
\text { real economy }\end{array}$ \\
\hline Novosibirsk State University & 2 & 72 & 8 & 1 & 19 \\
\hline $\begin{array}{l}\text { Novosibirsk State Technical } \\
\text { University }\end{array}$ & 17 & 217 & 9 & 1 & 18 \\
\hline Tomsk State University $^{1}$ & 17 & 515 & 11 & 1 & 39 \\
\hline Tomsk Polytechnic University $^{1}$ & 22 & 547 & 25 & 2 & 128 \\
\hline
\end{tabular}

${ }^{1}$ Informatsionno-analiticheskie materialy po perspektivnym nauchnym i innovatsionnym razrabotkam obrazovatelnykh i nauchnykh organizatsiy [Informational and analytical materials on promising research and innovative development of educational and research institutions]. (2015). In: G. I. Bakhturin (Ed.). Issue 2. Moscow: Ministry of Education and Science of the Russian Federation.

${ }^{2}$ Informatsionno-analiticheskie materialy po perspektivnym nauchnym i innovatsionnym razrabotkam obrazovatelnykh i nauchnykh organizatsiy [Informational and analytical materials on promising research and innovative development of educational and research institutions]. (2015). In: G. I. Bakhturin (Ed.). Issue 2. Moscow: Ministry of Education and Science of the Russian Federation.

Another aspect of the problem is indicative planning, which is aimed mainly at the number of publications abstracted in international citation databases. Besides, the rush toward quantitative indicators significantly reduces the quality of knowledge generated; an entire administrative resource in universities is concentrated in a limited number of functional areas. Commercialization of knowledge receives residual attention (and resources) by university management. Small innovative enterprises established by universities in the vast majority do not work above the stage of prototyping, i.e. they do not earn a profit. The best of our knowledge, there are no precedents in the academic startup achievement of the mass production stage; respectively, universities do not receive equity income.
One of the most common sources of funding in the Russian science is competitive public funding (grants, federal target programs). At the same time, the lion's share of public funding is accounted for the federal government and foundations (Figure 3).

Thus, the share of regional budgets is only one percent of the total volume of research funding. Naturally, with such a structure of financing, it is difficult to construct an optimal mechanism of universities' engagement in the regional economic systems. Hence, a perspective direction of educational policy change is seen to be an increase in the proportion of «regional» grants, which will contribute to the solution of specific problems of regional economic systems. Such a mechanism exists, but their amount of funding on 


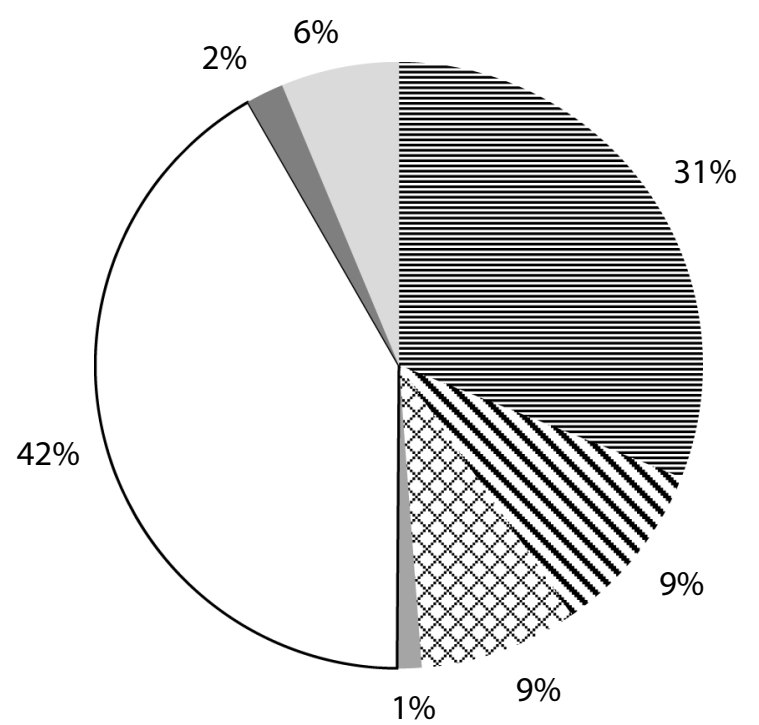

三Ministry of Education and Science

Other federal ministries

Foundations for support of scientific and technical activities

Regional budgets

$\square$ Business

Foreign sources

Other

Fig. 3. Research funding, kRub, by sources Nauchnyy potentsial vuzov i nauchnykh organizatsiy Ministerstva obrazovaniya i nauki [The scientific potential of the HEls and scientific organizations of the Ministry of Education and Science. 2015]. (2016). In: A. O. Ladny (Ed.). Saint Petersburg: Saint Petersburg Electrotechnical University

the scale of national science is close to the statistical error. For example, the Russian Foundation for Basic Research in 2013 allocated for regional grants only 23.1 million rubles, while the overall amount of funding was 7.6 billion rubles ${ }^{1}$. Just for the record, an extremely small amount of research funding from foreign sources means largely closed nature of the Russian science.

\section{Conclusions}

University as the key producer of knowledge in the region plays the central role in the regional entrepreneurial economic systems. The problem is that universities' impact on the economy is a very complicated and multidimensional phenomenon $[14,15]$. In this paper, we compared different techniques of entrepreneurial capacity measurement in terms of university rankings. The vast majority of the world rankings measure exclusively academic performance (publications, citations, internalization); meanwhile, innovative rankings lack available statistical indicators.

The number of Russian universities in global rankings is very small. With regard to the knowledge transfer, the figures are still very far from the best global samples. Real effective mechanisms of universities' engagement into regional economic systems are not available. Grounding on the comparative analysis of Novosibirsk and Tomsk universities, we can formulate the conditions of de-

\footnotetext{
${ }^{1}$ Panchenko, V. Ja. (2014). Otchet o deyatelnosti RFFI za 2013 god [RFBR report for 2013]. Retrieved from: http://www.rfbr. $\mathrm{ru} / \mathrm{rffi} / \mathrm{ru} /$ annotated_project_reports/o_1897126 (date of access: 04.03 .2017$)$.
}

velopment and realization of the entrepreneurial potential of the regional university:

1 . The growing volume of capital investment should support the demand for research and development in the region.

2. Compliance of research areas with technological priorities of the regional development; in turn, the latter should correspond to the real structure of the economy. The maximum effect is achieved in terms of the innovative development of traditional industries.

3 . The University should succeed in the development of the entire chain of knowledge generation, the first element of which is the basic research. Attempts to divide science from innovation negatively affect the final result.

4. Effective cooperation of academia, business, and government is supported not only by formal mechanisms, but also through informal institutions (especially in Russia).

The constraint in the development of cooperation between university and region is the fact that the vast majority of public funding is being allocated by the federal center, regional interests, in this case, are not considered. The results of this study will be used for the purposes of further analysis; in particular, we plan to analyze the regional cases using the tools of institutional economics. Furthermore, the results can be used in making educational policy decisions, because the existing system of indicative planning leads to the onesided development of universities focusing solely on the number of publications. 


\section{Acknowledgements}

The authors would like to express their deepest gratitude to the Russian Scientific Foundation for the support of the research within the project No. 15-18-10014 «Designing optimal social and economic systems in the context of turbulence of external and internal environment».

\section{References}

1. Blanqui, M. (1845). Histoire de l'économie politique en Europe: depuis les anciens jusquà nos jours, suivie d'une bibliographie raisonnée des principaux ouvrages déconomie politique (3rd ed.). Paris: Guillaumin. 820p.

2. Etzkowitz, H. (2002). Incubation of incubators: Innovation as a triple helix of university-industry-government networks. Science and Public Policy, 29(2), 115-128.

3. Etzkowitz, H., \& Leydesdorff, L. (2000). The dynamics of innovation: From National Systems and "mode 2" to a Triple Helix of university-industry-government relations. Research Policy, 29(2), 109-123.

4. Etzkowitz, H., \& Klofsten, M. (2005). The innovating region: Toward a theory of knowledge-based regional development. R and D Management, 35(3), 243-255. Retrieved from: http://doi.org/10.1111/j.1467-9310.2005.00387.x.

5. Acs, Z. J., \& Szerb, L. (2007). Entrepreneurship, economic growth and public policy. Small Business Economics, 28(2-3), 109-122. Retrieved from: http://doi.org/10.1007/s11187-006-9012-3.

6. Glaeser, E. L., \& Kerr, W. R. (2009). Local industrial conditions and entrepreneurship: How much of the spatial distribution can we explain? Journal of Economics and Management Strategy, 18(3), 623-663. Retrieved from: http://doi. org/10.1111/j.1530-9134.2009.00225.x.

7. Guesnier, B. (1994). Regional Variations in New Firm Formation in France. Regional Studies, 28(4), 347-358. Retrieved from: http://doi.org/10.1080/00343409412331348316.

8. Reynolds, P., Storey, D. J., Westhead, P., David, J., \& Comparisons, P.C. (1994). Cross-national Comparisonsofthe Variation in New Firm Formation Rates. Regional Studies, 28(4), 443-456. Retrieved from: http://doi.org/10.1080/00343400701232280

9. Lazzeretti, L., \& Tavoletti, E. (2005). Higher education excellence and local economic development: The case of the entrepreneurial University of Twente. European Planning Studies, 13(3), 457-493.

10. Schubert, T., \& Kroll, H. (2016). Universities' effects on regional GDP and unemployment: The case of Germany. Papers in Regional Science, 95(3), 467-489.

11. Temel, S., Durst, S., Yesilay, R. B., Hinteregger, C., Sukan, F. V., \& Uzkurt, C. (2015). The drivers of entrepreneurial universities in emerging economies: A Turkish case study. In Ferreira, J. J., Fernandes, C., and Raposo, M. L. Handbook of Research on Global Competitive Advantage through Innovation and Entrepreneurship, 569-588). DOI: 10.4018/978-1-46668348-8.ch019.

12. Guerrero, M., Urbano, D., \& Fayolle, A. (2014). Entrepreneurial activity and regional competitiveness: evidence from European entrepreneurial universities. Journal of Technology Transfer, 41, 105-131. Retrieved from: http://doi.org/10.1007/ s10961-014-9377-4.

13. North, D. C. (1990). Institutions, institutional change, and economic performance. BOOK, Cambridge; New York: Cambridge University Press. 164p.

14. Thanki, R. (1999). How do we know the value of higher education to regional development? Regional Studies, 33(1), $84-89$.

15. Popov, E. V., Vlasov, M. V. \& Simakhina, M. O. (2009). Ekonomika znaniya: instituty regionalnogo razvitiya [Economy of Knowledge: the Institutes of Regional Development]. Zhurnal ekonomicheskoy teorii [Russian Journal of Economic Theory], 3, 5-12. (In Russ.)

\section{Authors}

Dmitry Mikhaylovich Kochetkov - Research Assistant, Institute of Economics of the Ural Branch of RAS; Senior Analyst, Center for Regional Economic Studies, Graduate School of Economics and Management, Ural Federal University (19, Mira St., Ekaterinburg, 620002, Russian Federation; e-mail: kochetkovdm@hotmail.com).

Viola Anatolyevna Larionova - PhD in Physics and Matematics, Associate Professor, Graduate School of Economics and Management, Ural Federal University (19, Mira St., Ekaterinburg, 620002, Russian Federation; e-mail: viola-larionova@ yandex.ru).

Darko Bozha Vukovic-Doctor of Economics, Professor, Senior Research Associate, National Research Tomsk Polytechnic University (30, Lenin Ave., Tomsk, 634050, Russian Federation; e-mail: vdarko@hotmail.rs). 